\title{
Frequency of HLA antigens in asbestos workers with and without pulmonary fibrosis
}

\author{
C C EVANS, H C LEWINSÖHN, JUNE M EVANS
}

British Medical fournal, 1977, 1, 603-605

\section{Summary}

HLA antigens were determined in 37 patients with asbestosis and 37 matched controls with equivalent asbestos exposure but no pulmonary fibrosis, All had worked in the same textile factory. No significant differences in the prevalence of antigens were found between the two groups or between either group and controls who had not been exposed to asbestos. When the data were combined with findings from other pilot studies the previously suggested association between asbestosis and HLA-B27 was not confirmed. Subjects who were positive for HLA-B12 tended also to have advanced radiographic fibrosis. Asbestos workers without pulmonary fibrosis had an unexpectedly high frequency of HLA-BW5, which might indicate that this antigen protects against the development of pulmonary fibrosis.

\section{Introduction}

Merchant $e t$ al suggested, in a pilot study of 56 asbestos workers, ${ }^{1}$ that the HLA antigen B27 might provide a useful marker of enhanced human susceptibility to the damaging effects of asbestos dust on the lungs. At a recent international conference it was reported ${ }^{2}$ that $27 \%$ of 22 asbestos workers with alleged asbestosis had HLA-B27 compared with $9 \cdot 8^{\circ},{ }_{0}$ of control workers without asbestosis. In neither series were the criteria for the diagnosis of asbestosis given, nor was the prevalence of all the HLA antigens in workers with asbestosis tabulated. We could not therefore perform a combined analysis of the results.

This paper reports the prevalence of HLA antigens in asbestos workers with and without pulmonary fibrosis, in white-collar workers from the same asbestos textile factory, and in a large group of healthy blood donors in a nearby city.

\section{Subjects and methods}

Forty-four asbestos textile workers, most of whom were retired, had been certified by the pneumoconiosis panel as having asbestosis. They had worked in carding, spinning, twisting, handling, and supervising asbestos textiles in the same factory and their relevant occupational history is summarised in table I. We subsequently diagnosed pulmonary fibrosis due to asbestos dust inhalation in 37 of the 44 workers. These workers were unrelated Caucasians, and we rejected others because they did not satisfy stringent criteria for the diagnosis of the disease-that is, dyspnoea on effort; persistent end-inspiratory crepitations with or without finger clubbing; reduction in forced vital capacity, forced expiratory volume in one second, and single breath transfer factor; and positive radiographic features using the ILO/UC/ $1971^{3}$ classification of pneumoconiosis. By convention only

Department of Medicine, University of Liverpool, Liverpool L69 3BX C C EVANS, MD, MRCP, senior lecturer in medicine

- JUNE M EVANS, laboratory technician

TBA Industrial Products Ltd, Rochdale, Lancs

H C LEWINSÖHN, MB, DIH, chief medical officer (now corporate medical director, Raybestos Manhattan, Trumbell, Connecticut 06611, USA) small irregular pulmonary opacities were considered and pleural opacities were ignored. The following observations were recorded from the medical records: the age and year of entry into the factory, the number of years of exposure to asbestos dust, job title, smoking habits, and the age at which asbestosis was diagnosed. We then obtained from the medical records a group of employees with comparable occupational exposure who were not suffering from asbestosis. After the nature of the investigation had been explained to all $\mathbf{7 4}$ workers a new clinical examination was made, pulmonary function tests were repeated when possible, and the most recent chest radiograph was reviewed. A $20-\mathrm{ml}$ sample of venous blood was taken into a heparinised container for tissue typing and into a plain tube for antinuclear antibody (ANA) and rheumatoid factor determinations. HLA typing was performed on fresh unfrozen lymphocytes by the two-stage microlymphocytotoxic method using 26 antisera specificities obtained from the National Tissue Typing Reference Laboratory, Bristol. ABO antigens were typed by standard methods and ANA and rheumatoid factor were estimated by the method of Soutar, ${ }^{4}$ positive results being at a dilution of $1 / 8$ or greater.

Forty volunteer white-collar workers at the same factory were tissue typed and their results were compared with those of 616 blood donors from Merseyside, who acted as controls.

Statistical analyses for pulmonary function were made with Student's $t$ test and for other comparisons with Fisher's exact test.

\section{Results}

Table I summarises the clinical, physiological, serological, and radiological findings in 37 subjects with asbestosis (group 1) and the matched subjects free from pulmonary fibrosis (group 2). These subjects were closely matched for occupational exposure. Rheumatoid factor was present in almost as many controls as patients with asbestosis -a finding confirmed in the white collar workers (7 out of $40(18 \%)$ had rheumatoid factor at a titre of $1 / 8$ or greater).

Table II gives the prevalence of HLA antigens in the two matched groups, the 40 factory controls (group 3), and the 616 blood donors (group 4). There seemed to be an increased prevalence of HLA-B12 in group 1 and HLA-BW5 in group 2 . No differences were observed in the prevalence of HLA-B27. No significant differences existed for any other antigens between any of the groups.

Table III shows statistical comparisons for the three HLA-B antigens 12,27 , and W5 between all the groups. There were no significant differences between the two control groups who had not been exposed to asbestos-groups 3 and 4. The prevalence of HLA-B12 was higher in group 1 than in group 4, whereas HLA-BW5 was more prevalent in group 2 than in group 4 and group 1 . The relative risk of asbestosis in people with HLA-B12 was thus 2.37 when compared with that in healthy volunteers, but the probability was no more than that expected by chance $(P \cdot 0 \cdot 05)$ when $P$ was multiplied by the number of specificities tested. Except for B27 we would not perform a combined analysis of our results and those of the previous two studies. ${ }^{12}$ The relative risk for people with $\mathrm{B} 27$, calculated from all three series, was, however only $1.87\left(\%^{2}=1.96 ; \mathrm{P}>0.05\right)$ (table IV).

When the three $B$ series antigens were examined in relation to the radiographic category (table $\mathrm{V}$ ) there was a definite but insignificant association between the presence of HLA-B12 and radiographically severe disease and BW5 and clear radiographs.

In neither group 1 nor group 2 were there any differences in respect of the presence or absence of these antigens when cross-tabulated with the length of exposure, year of first exposure, age of first exposure, or the presence or absence of ANA.

\section{Discussion}

Most doctors specialising in occupational medicine agree that differences exist in the severity of pulmonary reactions in people 
TABLE I-Occupational, clinical, physiological, serological, and radiological data on 74 textile workers who had been exposed to asbestos, half of whom had asbestosis

\begin{tabular}{|c|c|c|c|c|c|c|c|c|c|c|c|c|c|c|c|c|c|c|c|c|c|c|c|c|c|c|c|}
\hline & \multirow{2}{*}{$\begin{array}{c}\text { No of } \\
\text { sub- } \\
\text { jects }\end{array}$} & \multirow{2}{*}{$\begin{array}{c}\text { Sex } \\
(\mathrm{M}: \mathrm{F})\end{array}$} & \multicolumn{3}{|c|}{$\begin{array}{c}\text { Age } \\
\text { (years) }\end{array}$} & \multicolumn{3}{|c|}{$\begin{array}{c}\text { Year } \\
\text { entered }\end{array}$} & \multicolumn{4}{|c|}{$\begin{array}{c}\text { Age } \\
\text { entered }\end{array}$} & \multicolumn{4}{|c|}{$\begin{array}{l}\text { Years } \\
\text { exposed }\end{array}$} & \multirow[t]{2}{*}{$\begin{array}{l}\text { No who } \\
\text { smoked }\end{array}$} & \multirow{2}{*}{$\begin{array}{l}\text { No } \\
\text { with } \\
\text { club- } \\
\text { bing }\end{array}$} & \multirow{2}{*}{$\begin{array}{c}\text { No } \\
\text { with } \\
\text { crepita- } \\
\text { tions }\end{array}$} & \multicolumn{3}{|c|}{$\begin{array}{l}\text { " of predicted } \\
\text { value }\end{array}$} & \multirow{2}{*}{$\begin{array}{c}\text { No } \\
\text { with } \\
\text { ANA }\end{array}$} & \multirow{2}{*}{$\begin{array}{c}\text { No } \\
\text { with } \\
\text { RF }\end{array}$} & \multicolumn{3}{|c|}{$\begin{array}{l}\text { Radiographic } \\
\text { profusion } \\
\text { category } \dagger\end{array}$} \\
\hline & & & $\mid<55$ & -59 & 760 & $<<1930$ & $\overline{-1949}$ & 1950 & $<20$ & -29 & -39 & 40 & $<20$ & -29 & -39 & 40 & & & & $\mathrm{FVC}$ & $\mathrm{FEV}_{1}$ & $\Gamma_{\mathrm{L}} \mathrm{CO}$ & & & 0 & 1 & 2 \\
\hline Group 1 & 37 & $27: 10$ & 2 & 7 & 28 & 12 & 18 & 7 & 11 & 11 & 11 & 4 & 7 & 11 & 13 & 6 & 28 & 16 & 37 & $\begin{array}{c}78 \cdot 5 \\
\pm \\
16 \cdot 5 \\
94 \cdot 1\end{array}$ & $\begin{array}{c}76 \cdot 8 \\
\pm \\
18 \cdot 1 \\
87 \cdot 1\end{array}$ & \begin{tabular}{|c|}
66.9 \\
\pm \\
13.7 \\
96.3
\end{tabular} & 12 & 9 & 2 & 22 & 13 \\
\hline Group 2 & 37 & $28: 9$ & 3 & 9 & 25 & 9 & 21 & 7 & 11 & 14 & 8 & 4 & 3 & 14 & 13 & 7 & 27 & $1^{*}$ & $1^{*}$ & $\frac{ \pm}{17 \cdot 3}$ & $\stackrel{ \pm}{ \pm}$ & $\begin{array}{c} \pm \\
19 \cdot 8\end{array}$ & 1 & 7 & 30 & 7 & 0 \\
\hline$\overline{x^{2}}$ & & & & & & & & & & & & & & & & & & \begin{tabular}{|c|}
14.97 \\
$<0.001$
\end{tabular} & $\mid \begin{array}{c}66.26 \\
<0.001\end{array}$ & $\mid<0.001$ & $<0.05$ & $\mid<0.001$ & $\begin{array}{r}9.33 \\
<0.01 \\
\end{array}$ & & & $\begin{array}{l}45 \cdot 26 \\
0 \cdot 001\end{array}$ & \\
\hline
\end{tabular}

*Bronchiectasis.

*Bronchiectasis.
+Profusion category $0=0 /-, 0 / 0$, and $0,1.1=1 / 0,1 / 1$, and $1,2.2=2 ; 1,2 / 2$, and $2 ; 3$

TABLE II-Prevalence of HLA antigens in groups 1, 2, 3, and 4 and groups 1 and 2 combined

\begin{tabular}{|c|c|c|c|c|c|c|c|c|c|c|}
\hline \multirow{2}{*}{ HLA } & \multicolumn{2}{|c|}{$\underset{(n=37)}{\text { Group } 1}$} & \multicolumn{2}{|c|}{$\underset{(n=37)}{\text { Group } 2}$} & \multicolumn{2}{|c|}{$\begin{array}{l}\text { Group } 3 \\
(n=40)\end{array}$} & \multicolumn{2}{|c|}{$\begin{array}{l}\text { Group 4 } \\
(\mathrm{n}=616)\end{array}$} & \multicolumn{2}{|c|}{$\begin{array}{l}\text { Groups } \\
1 \text { and } 2\end{array}$} \\
\hline & No & $\%$ & No & $\%$ & No & $\%$ & No & $\%$ & No & $\%$ \\
\hline \multicolumn{11}{|c|}{ HL $A$ antigens $A$ locus } \\
\hline $\begin{array}{r}1 \\
2 \\
3 \\
9 \\
10 \\
11 \\
28 \\
W 29 \\
W 32\end{array}$ & $\begin{array}{r}14 \\
18 \\
6 \\
10 \\
2 \\
4 \\
4 \\
2 \\
2\end{array}$ & \begin{tabular}{|}
$(37.8)$ \\
$(48.6)$ \\
$(16.2)$ \\
$(27.0)$ \\
$(5.4)$ \\
$(10.8)$ \\
$(10.8)$ \\
$(5.4)$ \\
$(5.4)$
\end{tabular} & $\begin{array}{r}14 \\
16 \\
12 \\
5 \\
2 \\
5 \\
2 \\
3 \\
4\end{array}$ & \begin{tabular}{|}
$(37.8)$ \\
$(43.2)$ \\
$(32.4)$ \\
$(13.5)$ \\
$(5.4)$ \\
$(13.5)$ \\
$(5.4)$ \\
$(8.1)$ \\
$(10.8)$
\end{tabular} & $\begin{array}{r}10 \\
23 \\
15 \\
4 \\
6 \\
4 \\
3 \\
3 \\
7\end{array}$ & $\begin{array}{r}(25) \\
(57.5) \\
(37.5) \\
(10.0) \\
(15.0) \\
(10.0) \\
(7.5) \\
(7.5) \\
(17.5)\end{array}$ & $\begin{array}{r}195 \\
266 \\
148 \\
83 \\
40 \\
56 \\
46 \\
\text { NT } \\
\text { NT }\end{array}$ & $\begin{array}{r}(31 \cdot 7) \\
(43 \cdot 2) \\
(24 \cdot 0) \\
(13.5) \\
(6.5) \\
(9 \cdot 1) \\
(7 \cdot 5)\end{array}$ & $\begin{array}{r}28 \\
34 \\
18 \\
15 \\
4 \\
9 \\
6 \\
5 \\
6\end{array}$ & $\begin{array}{r}(37.8) \\
(45.9) \\
(24.3) \\
(20.3) \\
(5.4) \\
(12.2) \\
(8.1) \\
(6.8) \\
(8.1)\end{array}$ \\
\hline \multicolumn{11}{|c|}{$H L A$ antigens $B$ locus } \\
\hline $\begin{array}{r}5 \\
7 \\
8 \\
12 \\
13 \\
14 \\
15 \\
17 \\
27 \\
\text { W5 } \\
\text { W10 } \\
\text { W15 } \\
\text { W16 } \\
\text { W18 } \\
\text { W21 } \\
\text { W22 } \\
\text { TY }\end{array}$ & $\begin{array}{r}2 \\
6 \\
10 \\
18 \\
2 \\
4 \\
1 \\
5 \\
2 \\
1 \\
3 \\
4 \\
0 \\
8 \\
2 \\
1 \\
0\end{array}$ & $\begin{array}{r}(5.4) \\
(16.2) \\
(27.0) \\
(48.6) \\
(5.4) \\
(10.8) \\
(2.7) \\
(13.5) \\
(5.4) \\
(2.7) \\
(8.1) \\
(10.8) \\
\\
(21.6) \\
(5.4) \\
(2.7)\end{array}$ & $\begin{array}{r}6 \\
7 \\
10 \\
10 \\
2 \\
3 \\
0 \\
3 \\
3 \\
9 \\
7 \\
3 \\
1 \\
3 \\
2 \\
3 \\
2\end{array}$ & \begin{tabular}{|}
$(16.2)$ \\
$(18.9)$ \\
$(27.0)$ \\
$(27.0)$ \\
$(5.4)$ \\
$(8.1)$ \\
$(8.1)$ \\
$(8.1)$ \\
$(24.3)$ \\
$(18.9)$ \\
$(8.1)$ \\
$(2.7)$ \\
$(8.1)$ \\
$(5.4)$ \\
$(8.1)$ \\
$(5.4)$
\end{tabular} & $\begin{array}{r}3 \\
16 \\
7 \\
13 \\
0 \\
2 \\
0 \\
1 \\
2 \\
3 \\
11 \\
8 \\
6 \\
3 \\
0 \\
1 \\
2\end{array}$ & $\begin{array}{r}(7.5) \\
(40.0) \\
(17.5) \\
(32.5) \\
(5.0) \\
(2.5) \\
(5.0) \\
(7.5) \\
(27.5) \\
(20.0) \\
(15.0) \\
(7.5) \\
(2.5) \\
(5.0)\end{array}$ & $\begin{array}{r}37 \\
151 \\
157 \\
185 \\
18 \\
46 \\
\text { NT } \\
46 \\
40 \\
49 \\
56 \\
40 \\
\text { NT } \\
\text { NT } \\
\text { NT } \\
\text { NT }\end{array}$ & $\begin{array}{r}(6.0) \\
(24.5) \\
(25.5) \\
(30.0) \\
(2.9) \\
(7.5) \\
(7.5) \\
(6.5) \\
(8 \cdot 0) \\
(9 \cdot 1) \\
(6.5)\end{array}$ & $\begin{array}{r}8 \\
13 \\
20 \\
28 \\
4 \\
7 \\
1 \\
8 \\
5 \\
10 \\
10 \\
7 \\
1 \\
11 \\
4 \\
4 \\
2\end{array}$ & \begin{tabular}{|c}
$(10.8)$ \\
$(17.6)$ \\
$(27.0)$ \\
$(37.8)$ \\
$(5.4)$ \\
$(9.5)$ \\
$(1.4)$ \\
$(10.8)$ \\
$(6.8)$ \\
$(13.5)$ \\
$(13.5)$ \\
$(9.5)$ \\
$(1.4)$ \\
$(14.9)$ \\
$(5.4)$ \\
$(5.4)$ \\
$(2.7)$
\end{tabular} \\
\hline
\end{tabular}

$\mathrm{NT}=$ Not tested

with similar exposure to asbestos dust. The finding of an increased frequency of ANA and rheumatoid factor in subjects with asbestosis ${ }^{5}$ suggests that host factors may change an individual's response, and such autoantibodies raise the possibility of inherited differences in susceptibility to asbestosis. The major histocompatibility system in man is thought to be closely linked with genes controlling immunological responses, and associations with other disorders have been established. ${ }^{6}$ The prior identification of men at risk when handling asbestos is an obvious occupational health goal. Our investigation was justified by previous pilot studies that showed encouraging results but lacked adequate controls and numbers.

Our results have not confirmed these encouraging findings. ${ }^{12}$ We found no association between HLA-B27 and the development and severity of asbestosis. There are several reasons for the discrepancy between our findings and those of the earlier studies. Merchant $e t$ al $^{1}$ studied 56 subjects referred to a pneumoconiosis panel, but they did not specify the criteria for establishing the diagnosis of asbestosis. When they reviewed the radiographs they found that HLA-B27 was present in six out of 19 subjects with radiographic profusion of $2 / 1$ or greater (on UICC classification (1971)). They found that the length of exposure to asbestos was shorter and the first exposure more recent in the 10 workers who were positive for HLA-B27, although at least four of these probably did not have asbestosis and such small numbers are not significant. Most of their subjects worked in the insulation industry or dockyards and might have had a mixed exposure to different types of asbestos. The dust levels in these occupations vary and have been high in the past. In contrast, our subjects all worked in a single asbestos textile factory and were predominantly exposed to chrysotile asbestos, although the older and longer-serving employees had once been exposed to much higher levels than those today, and small quantities of crocidolite may also have been present in the environment then.

Matej and Lange ${ }^{2}$ studied 134 workers from a Polish factory and reported that HLA-B27 was 3.44 times more common among these workers than among the control population, but they gave no indication of the diagnostic criteria for asbestosis in the 22 workers deemed to be affected. Combining the data on HLA-B27 in the two previous reports and our study (table IV) shows that the association is not statistically significant.

TABLE III-Comparison* of prevalence of $H L A, B 12, B 27, B W 5$ in the four groups studied

\begin{tabular}{|c|c|c|c|}
\hline & HLA B12 & HLA B27 & HLA BW5 \\
\hline $\begin{array}{lll}1 & v & 2 \\
1 & v & 3 \\
1 & v & 4 \\
2 & v & 3 \\
2 & v & 4 \\
3 & v & 4\end{array}$ & $\begin{array}{l}\chi^{2}=2.82 ; P=0.093 \\
\chi^{2}=1.47 ; P=0.23 \\
\chi^{2}=4.81 ; P=0.028 \\
\chi^{2}=0.076 ; P=0.78 \\
\chi^{2}=0.041 ; P=0.84 \\
\chi^{2}=0.023 ; P=0.88\end{array}$ & $\begin{array}{l}P=1.0 \dagger \\
P=1.0 \dagger \\
\chi^{2}=0 ; P=1.0 \\
P=0.93 \dagger \\
\chi^{2}=0.002 ; P=0.96 \\
\chi^{2}=0.002 ; P=0.96\end{array}$ & $\begin{array}{l}P=0.014 \\
P=0.67 \\
\chi^{2}=0.72 ; P=0.40 \\
P=0.044 \\
\chi^{2}=9.62 ; P=0.0019 \\
\chi^{2}=0 ; P=1.0\end{array}$ \\
\hline
\end{tabular}

* $\chi^{2}$ tests: $\mathrm{DF}=1$; Yates's correction.

tFisher's exact test.

TABLE IV-Prevalence of $H L A, B 27$ in patients with asbestosis in this and other studies

\begin{tabular}{|c|c|c|c|c|c|}
\hline \multirow{2}{*}{ Study } & \multirow{2}{*}{$\begin{array}{l}\text { No of } \\
\text { subjects }\end{array}$} & \multicolumn{2}{|c|}{ Asbestosis } & \multicolumn{2}{|c|}{ Controls } \\
\hline & & $\begin{array}{l}\text { Positive } \\
\text { for B27 }\end{array}$ & $\begin{array}{l}\text { Negative } \\
\text { for B27 }\end{array}$ & $\begin{array}{l}\text { Positive } \\
\text { for B27 }\end{array}$ & $\begin{array}{l}\text { Negative } \\
\text { for B27 }\end{array}$ \\
\hline $\begin{array}{l}\text { Merchant et al }{ }^{1} \\
\text { Matej and Lange }{ }^{2} \\
\text { Present study }\end{array}$ & $\begin{array}{r}56 \\
134 \\
74\end{array}$ & $\begin{array}{l}6 \\
5 \\
2\end{array}$ & $\begin{array}{l}13 \\
17 \\
35\end{array}$ & $\begin{array}{r}4 \\
11 \\
3\end{array}$ & $\begin{array}{r}33 \\
101 \\
34\end{array}$ \\
\hline
\end{tabular}

Combined relative risk $=1.87 . \chi^{2}=1.96 ; \mathrm{P}>0.05$

TABLE $\mathrm{V}-N$ umber of subjects exposed to asbestos with and without HLA antigens $B 12, B 27$, and $B W 5$ and their radiographic categories as judged by ILO-UC profusion criteria

\begin{tabular}{|c|c|c|c|c|c|c|}
\hline \multirow{2}{*}{$\begin{array}{l}\text { ILO-UC } \\
\text { profusion } \\
\text { category* }\end{array}$} & \multicolumn{2}{|c|}{ B12 } & \multicolumn{2}{|c|}{ B27 } & \multicolumn{2}{|c|}{ BW5 } \\
\hline & Positive & Negative & Positive & Negative & Positive & Negative \\
\hline $\begin{array}{l}0 \\
1 \\
2\end{array}$ & $\begin{array}{r}9 \\
11 \\
8\end{array}$ & $\begin{array}{r}23 \\
18 \\
5\end{array}$ & $\begin{array}{l}3 \\
2 \\
0\end{array}$ & $\begin{array}{l}29 \\
27 \\
13\end{array}$ & $\begin{array}{l}9 \\
1 \\
0\end{array}$ & $\begin{array}{l}23 \\
28 \\
13\end{array}$ \\
\hline Total: & 28 & 46 & 5 & 69 & 10 & 64 \\
\hline
\end{tabular}

*See footnote to table I for definition of profusion categories. 
If the association between a disease and the HLA system is strong only relatively small numbers of patients and controls are necessary to confirm it, but when the association is weak, problems of sampling and statistical errors assume greater importance. These have been reviewed, ${ }^{7}$ and so far none of the reported associations between HLA antigens and asbestosis have achieved significance when the probability value has been multiplied by the total number of antigens tested. Ignoring the trend may, however, obscure the association, and further data should be obtained.

HLA-B12 was found in 18 of our $37\left(49_{\circ}^{\circ}\right)$ patients with asbestosis. This antigen was also found in 16 out of $20\left(80^{\circ}{ }_{0}\right)$ patients with cryptogenic fibrosing alveolitis ${ }^{\star}$ - a disorder similar to asbestosis but without the history of occupational exposure -and in four out of eight children with the highly pathogenic strain of Haemophilus influenza serotype B. ${ }^{9}$

If HLA-B12 does increase susceptibility to the damaging effects of asbestos on the lung and to the development of cryptogenic fibrosing alveolitis, this would imply that in the HLA region of chromosome 6 in man a pulmonary fibrogenic gene is in linkage disequilibrium with HLA-B12. Since the external agent in asbestosis is known it may prove possible to elucidate further the pathogenesis of asbestosis and the significance of the interaction of the HLA antigens with environmental precipitating factors in general.

The high prevalence of HLA-BW5 (tables II-V) in exposed workers without asbestosis and with clear radiographs raises the possibility that possession of this antigen may protect against the development of pulmonary fibrosis. This is not an entirely new concept since it has been shown that progressive massive fibrosis (PMF) occurs in a low percentage of coalminers ${ }^{10}$ with HLA-BW18. Moreover, patients with carcinoma of the bronchus survive longer after pneumonectomy ${ }^{11}$ if they are positive for HLA-BW19 and B5.

When exploring HLA associations with disease, studies of families offer confirmation of the findings, ${ }^{12}$ but it is unlikely that this will be possible in asbestos workers, who, unlike coalminers and cotton workers, do not traditionally follow relatives into similar work.

If further studies of HLA antigens are made in this disorder we cannot emphasise too strongly the need for applying rigid criteria for the diagnosis. ${ }^{13}$ Only in this way will meaningful results be obtained and those with an increased risk be recognised.

We thank Mrs A Knott for meticulous care in matching the controls and performing the pulmonary function tests and $\mathrm{Dr} M$ Perkin for collecting many of the samples. We also thank Mr C West, who gave valuable statistical advice.

\section{References}

${ }^{1}$ Merchant, J A, et al, British Medical fournal, 1975, 1, 189.

${ }^{2}$ Matej, H, and Lange, A, First International Symposium on $H L A$ and Disease, p 256. Paris, INSERM, 1976.

${ }^{3}$ International Classification of Radiographs of Pneumoconiosis, ILO-UC Classification, 1971. Geneva, International Labour Office, 1972.

${ }^{4}$ Soutar, C A, Turner-Warwick, M, and Parkes, W R, British Medical fournal, 1974, 3, 145.

5 Turner-Warwick, M, and Parkes, W R, British Medical fournal, 1970, 3, 492.

'Svejgaard, A, et al, Transplantation Reviews, 1975, 22, 3.

7 Svejgaard, A, et al, Tissue Antigens, 1974, 4, 95.

${ }^{8}$ Evans, C C, Thorax, 1976, 31, 483.

9 Tejani, A, et al, First International Symposium on HLA and Disease. p 264. Paris, INSERM, 1976.

${ }^{10}$ Major, P C, et al, American Review of Respiratory Diseases, 1975, 3, 917.

11 Rogantine, G M, and Dellon, P B, fournal of the National Cancer Institute, $1975,54,1283$.

12 Cudworth, A G, and Woodrow, J C, British Medical fournal, 1975, 3, 133.

13 Parkes, W R, Occupational Lung Disorders: London, Butterworths, 1974

(Accepted 6 Fanuary 1977)

\title{
Quinine-induced agranulocytosis: toxic effect of quinine bisulphate on bone marrow cultures in vitro
}

\author{
RUTH SUTHERLAND， P C VINCENT， E RAIK， K BURGESS
}

\section{Introduction}

Drug-induced agranulocytosis is a rare but potentially serious clinical problem, and in most cases the clinician can attempt to identify the causative agent only from the history and response to withdrawal. This is relatively simple with single-drug exposure but much more difficult, if not impossible, when several drugs have been used. Methods for identifying the causative agent in vitro are clearly desirable. We described a case of amodiaquine-induced agranulocytosis in which amodiaquine suppressed the in-vitro growth of marrow cells from the patient but not from a normal control. ${ }^{1}$ Since then a few other reports have appeared in which drugs known to have caused agranulocytosis have been tested against cultures of normal marrow cells but not against cells from patients with a suspected adverse reaction to the drug. ${ }^{2-4}$ Quinine is a documented but rare cause of agranulocytosis. ${ }^{5}$ We report a case in which it was proved in vitro to be the responsible agent.

\section{Clinical history}

A 64-year-old man with a five-year history of peripheral neuropathy and leg cramps was admitted to hospital for investigation. He had 